\title{
NOTES
}

\section{ADMINISTRATIVE LAW: JURISDICTION OF CIVIL AERONAUTICS BOARD IN ANTITRUST CONTROVERSIES EXTENDED BY THE SUPREME COURT}

\begin{abstract}
A BASIC PROBLEM of federal adminstrative law has been the conflict between administrative regulation of industry and the federal antitrust laws. In an attempt to avoid this conflict Congress has sometimes enacted legislative exemptions, ${ }^{1}$ whereby certain practices are exempted from the antitrust laws by the regulatory statute and thus are within the exclusive jurisdiction of the agency. However, in a number of instances the statutes involved have not been so specific and the courts have been faced with the problem of accommodating the regulatory scheme and the antitrust laws. The principal means of accommodation has been the doctrine of primary jurisdiction, ${ }^{2}$ under which a court refrains from exercising its jurisdiction over antitrust matters until the agency involved has determined those questions within its competency. ${ }^{3}$ The traditional
\end{abstract}

\footnotetext{
${ }^{I}$ See generally Note, Regulated Industries and the Antitrust Laws: Substantive and Procedural Coordination, 58 Conum. L. REv. 673, 679-80 \& n.56, 681 (1958). An example of such an exemption from the antitrust laws is $\S 414$ of the Civil Aeronautics Act of 1938, 52 Stat. 1004 (now Federal Aviation Act of 1958, as amended, 72 Stat. 770, 49 U.S.C. $\S 1384$ (1958)). An agency ruling under such a statute is subject to judicial review. Administrative Procedure Act $\$ 10,60$ Stat. 243 (1946), 5 U.S.C. $\S 1009$ (1958). Most of the exemptions from the antitrust laws are worded so that they will be effective only if the practice has been approved by the agency. Yet, even in instances where unapproved practices were attacked the courts have sent the cases to the agency to see whether the agency would approve the practice. See, e.g., Far East Conference v. United States, 342 U.S. 570 (1952); FuLdA, CoMperition IN THE RIgulated Industries: TRANSPORTATION $\$ 13.4$ (1961) [hereinafter cited as Fulda]; Note, 58 Colum. L. REv. 673, 681 (1958).

a See generally 3 Davis, Administrative Law Treatise ch. I9 (1958) [hereinafter cited as DAvIs]; FuLDA §13; Convisser, Primary Jurisdiction: The Rule and Its Rationalizations, 65 YALE L.J. 315 (1956); Jaffe, Primary Jurisdiction Reconsidered-The Anti-Trust Laws, 102 U. PA. L. REv. 577 (1954); Latta, Primary Jurisdiction in the Regulated Industries and the Antitrust Laws, 30 U. Cinc. L. REv. 261 (1961); Schwartz, Legal Restriction of Competition in the Regulated Industries: An Abdication of Judicial Responsibility, 67 HARv. L. Rev. 436 (1954); von Mehren, The Anti-trust Laws and Regulated Industries; The Doctrine of Primary Jurisdiction, 67 HARv, L. REv. 929 (1954); Note, 58 Colum. L. REv, 673 (1958).

33 DAvis $\$ 19.01$. In the usual situation there is a concurrence of jurisdiction. If the case is first brought into the courts, the defendant will often raise the doctrine of primary jurisdiction as a defense. If the courts defer to the primary jurisdiction of the agency, then the agency will first hear the case. This does not mean that the agency ruling is conclusive. For one thing, there is a right to judicial review of the
} 
reasons for invoking the doctrine of primary jurisdiction were: an attempt to achieve uniformity of regulation ${ }^{4}$ and deference to the alleged expertise of the agency. ${ }^{5}$ A somewhat different ground for referring a case to an agency is supersession, whereby the courts determine by statutory construction that the regulatory statute has superseded the antitrust laws. ${ }^{6}$ Since the antitrust laws have been superseded, the case is referred to the agency for determination under its standards subject only to judicial review. ${ }^{7}$ Thus, supersession is similar in effect to legislative exemption and endows the agency with not only primary but primary and exclusive jurisdiction over some antitrust matters. ${ }^{8}$

In the recent case of Pan American World Airways, Inc.v. United States, ${ }^{9}$ the United States Supreme Court held that the remedy of

agency ruling. Administrative Procedure Act $\$ 10,60$ Stat. 243 (1946), 5 U.S.C. $\S 1009$ (1958). Furthermore, the courts sometimes merely stay the antitrust proceedings pending the outcome of the agency proceedings. In such cases, a problem is raised as to the weight the court will give in its determination of the antitrust case to the findings, evaluations and determinations made by the agency in its proceeding. See 3 DAvis $\$ 19.07$; FuLDA $\$ 13.1$; Latta, supra note 2, at 267.

See, e.g., Texas \& Pac. Ry. v. Abilene Cotton Oil Co., 204 U.S. 426 (1907). See generally Mitchell, Primary Jurisdiction-What It Is and What It Is Not, 13 A.B.A. ANTITRUST SEc. REP. 26, 26-35 (1958).

See, e.g., Great No. Ry. v. Merchants Elevator Co., 259 U.S. 285, 291 (1922). See also FMB v. Isbrandtsen Co., 356 U.S. 481 (1958) (expertise as finders and interpreters of fact); United States v. Western Pac. R.R., 352 U.S. 59, 64 (1956) (primary jurisdiction based on both uniformity and expertise). See generally Mitchell, supra note 4, at 26-35. For a criticism of expertise as a criterion for invoking primary jurisdiction see Schwartz, supra note 2, at 471-75.

See Latta, supra note 2, at 266.67; cf. Note, 58 Corum. L. REv. 673, 681 (1958). Supersession is effected because of an apparent direct conflict between the regulatory statute and the antitrust laws. Since the regulatory statute is a more recent and more specific expression of congressional policy, the antitrust law is held to have been superseded. See, e.g., McLean Trucking Co. v. United States, 321 U.S. 67, 79 (1944) (statutory exemption case).

For examples of supersession see Far East Conference v. United States, 342 U.S. 570 (1952) (Federal Maritime Act); United States Nav. Co. v. Cunard S.S. Co., 284 U.S. 474 (1932) (same); Pennsylvania Water \& Power Co. v. FPC, 193 F.2d 230, 235 (D.C. Cir. 1951), aff'd, 343 U.S. 414 (1952) (Federal Power Commission Act). The Far East and Cunard cases arose under a section which gave the FMB the authority to exempt certain practices from the antitrust laws, but in neither case had the ap. proval of the FMB been sought. Nevertheless, the Court ruled that the antitrust laws had been superseded and the agency should hear the case and determine whether the practices were proper. Such a ruling does not mean that the policy of the antitrust laws will not play a part in the agency determination. However, an interesting question is to what extent antitrust policy should influence agency decisions. See notes 31-36 infra and accompanying text.

${ }^{7}$ See Latta, supra note 2 , at 276-77.

${ }^{8}$ See generally Note, 58 Colum. L. REv. 673, 681 (1958). It should be noted that in the usual circumstances the immunization from the antitrust laws is broader under statutory exemption than under supersession.

0371 U.S. 296 (1963). 
the Sherman Act had been superseded by section 411 of the Civil Aeronautics Act ${ }^{10}$ (CAA), which invests the Civil Aeronautics Board $(\mathrm{CAB})$ with power to issue cease and desist orders to protect the public interest from air carriers who engage in "unfair .. . practices or unfair methods of competition." Thus, the Court ruled that under section 411 the $\mathrm{CAB}$ had primary and exclusive jurisdiction coupled with a power of divestment over questions of territorial division, route allocations and combinations between common carriers and air carriers. ${ }^{11}$

In 1928 Pan American World Airways, lnc., and the steamship line W. R. Grace \& Co. formed, as 50 per cent owners, Pan American Grace Airways (Panagra). Under this agrecment Panagra was to operate on the West Coast of South America and Pan American was to serve the East Coast of South America and north of the Canal Zone. In 1938 Grace began a move to have Panagra petition the $\mathrm{CAB}$ for a route cxtension from the Canal Zone to the United States, but the directors controlled by Pan American refused to agree to such a petition. Thus, the conflict arose which eventually led to the Pan American case. ${ }^{12}$ The present suit was instituted by the

10 "The Board may, upon its own initiative or upon complaint by any air carrier, .... if it considers that such action by it would be in the interest of the public, investigate and determine whether any air carrier, ... has been or is engaged in unfair or deceptive practices or unfair methods of competition in air transportation .... If the Board shall find, after notice and hearing, that such air carrier, ... is engaged in such unfair or deceptive practices or unfair methods of competition, it shall order such air carrier, ... . to cease and desist from such practices or methods of competition."

Civil Aeronautics Act of 1938, $\$ 411,52$ Stat. 1003, amended by 66 Stat. 628 (1952) (now Federal Aviation Act of 1958, as amended, 72 Stat. 769, 49 U.S.C. $\$ 1381$ (1958)). See American Airlines, Inc. v. North American Airhines, Inc., 351 U.S. 79 (1956), which construes $\S 411$ in a case dealing with infringement of trade name.

12371 U.S. at 310 . The Court qualified its decision by stating that the Board did not have primary and exclusive jurisdiction over all antitrust issues. Id. at 311-12. The Court stated that the courts would still handle all criminal violations of the antitrust laws. This indicates that $\S 411$ was not given the broad immunization from all antitrust attacks that $\$ 414,49$ U.S.C. $\$ 1384$ (1958), accords transactions approved by the Board under $\$ \S 408,409$, and 412 , 49 U.S.C. $\$ \S 1378-79,1382$ (1958). See McManus v. $\mathrm{CAB}, 286 \mathrm{~F} .2 \mathrm{~d} 414,418$ (2d Cir.), cert. denied, 366 U.S. 928, rehearing denied, 366 U.S. 978 (1961). Furthermore, the Court did not state whether or not a private party could bring a civil suit in the courts.

${ }^{12}$ Brief for Respondent, pp. 7-19. In 1941 Grace filed a petition with the CAB to have Panagra's route extended. The Board dismissed on the ground that it could extend Panagra's route only if Panagra applied for the route extension. Panagra Terminal Investigation, 4 C.A.B. 670 (1944). This ruhing was reversed by the court of appeals, which held that the Board could entertain the application filed by Grace if Pan American's refusal to agree to the petition was based on "illegality or fraud." W.R. Grace \& Co. v. CAB, 154 F.2d 271, 281-82 (2d Cir. 1946). The Supreme Court granted certiorari, 328 U.S. 832 (1946), but later dismissed for mootness, 332 U.S. 827 
Justice Department and charged Pan American, Grace and Panagra with violations of sections 1,2 , and 3 of the Sherman Act. ${ }^{13}$ The district court dismissed the charges against Grace and Panagra, but found Pan American guilty of violating section 2 of the Sherman Act for excluding competition by use of its negative control position to prevent Panagra's application for a route extension.14

On direct appeal the Supreme Court reversed and denied the district court's jurisdiction over the antitrust issues of this case, noting that there would be an odd result if territorial divisions and route allocations which met the public interest standard of section 411 as defined in section 102 were later held by the courts to be antitrust violations. ${ }^{15}$ The Court circumvented this potential problem by construing the $\mathrm{CAA}$ as giving the $\mathrm{CAB}$ the authority to decide the antitrust issues presented in its disposition of the case. The Court first concluded that the phrases "unfair practices" and "unfair methods of competition" used in section 411 were intended to convey a broader meaning of competition in the context of the CAA than accorded at common law.16 Since under section 411 the $\mathrm{CAB}$ was to deal with unfair practices and competition when "it would be in

(1947) (per curiam), because the dispute had been settled by an agreement satisfactory to the Board. Pan American-Panagra Agreement, 8 C.A.B. 50 (1947).

${ }^{13}$ Sherman Antitrust Act $\$ \S 1-3,69$ Stat. 282 (1955), 15 U.S.C. $\$ \S 1-3$ (1958). It should be noted that the $\mathrm{CAB}$ is given the authority to enforce sections of the Clayton Act. Clayton Act $\$ 21,72$ Stat. 943, 15 U.S.C. $\$ 21$ (1958). For a list of the specific charges see United States v. Pan American World Airways, Inc., 193 F. Supp. 18, 21-22 (S.D.N.Y. 1961). It is also interesting to note that the CAB urged the suit, id. at 20 n.2, and had on several occasions expressed its dissatisfaction with the Panagra setup. See, e.g., New York-Balboa Through Service Proceedings Reopened, 18 C.A.B. 857, 914 (1954).

${ }^{14}$ United States v. Pan American World Airways, Inc., 193 F. Supp. 18, 36-46, 54 (S.D.N.Y. 1961). The district court also ordered Pan American to show why its holdings in Panagra should not be divested. Id. at 54. For other conclusions reached by the district court, see $i d$. at 22,23.

15371 U.S. at 309. The Court also stated that if the courts intervened "with their construction of the antitrust laws, two regimes might collide." Id. at 310 .

${ }^{10}$ The Court looked particularly at $\S 5$ of the Federal Trade Commission Act, 72 Stat. 1750, 15 U.S.C. $\S 45$ (1958), the acknowledged model for $\S 411$, as an aid in interpreting the scope of this language in $\$ 411$. American Airlines, Inc. v. North American Airlines, Inc., 351 U.S. 79, 85, 55 Mrch. L. Rev. 305 (1956); RHyne, CiviL AEronautics ACT ANnotated 146 \& n.501 (1939). For a good discussion of these phrases as used in $\$ 5$ of the Federal Trade Commission Act, which can easily be applied to $\$ 411$, see 2 Toulmin's ANTr-Trust Laws $\$ 43.1-.30$ (1949).

As the dissent pointed out, $\$ 5$ of the Federal Trade Commission Act has never been held to have superseded the antitrust laws. 371 U.S. at 324. See, e.g., FTC v. Cement Institute, 333 U.S. 683 (1948); United States v. Charles Pfizer \& Co., 205 F. Supp. 94 (S.D.N.Y. 1962). Yet, as a practical matter $\$ 5$ of the FTCA could not be held to supersede the antitrust laws because $\$ 5$ covers so much of the economy that the result would be a wholesale repeal of the antitrust laws. 
the interest of the public," the Court looked to section $102^{17}$ to see whether the issues of this case concerned the public interest in air transportation. The Court determined that the antitrust questions involved affected this public interest, and in so ruling noted particularly the language of section 102 which concerns "present and future needs" of air commerce, and "competition to the extent necessary to assure sound development." 18 Thus, by holding that the issues involved affected this public interest and that section 411 was intended to cover a wide range of unfair practices and competition that affect the public interest in air transportation, the Court determined that the antitrust issues presented came within the scope of the CAB's authority under section 411 .

Essential to the Court's holding were its findings that section 411 gave the $\mathrm{CAB}$ jurisdiction over pre-1938 transactions ${ }^{19}$ and a power to order divestments for violations of that section. ${ }^{20}$ The Court interpreted the section 411 language "has been or is engaged in unfair practices" as giving the CAB jurisdiction over pre-1938 transactions. $^{21}$ Such power was necessary if the act was to be administered as a whole, and thereby the $\mathrm{CAB}$ was given the authority to deal with route allocations and territorial divisions that were established before 1938. Further and more important, the Court determined that the cease and desist power of section 411 included a power to order divestment for violations of that section. The Court reasoned that Congress having given the $\mathrm{CAB}$ jurisdiction over the issues of this case must also have intended that the Board have sufficient power to deal with them. This finding of a power of divestiture was of principal importance for it enabled the remedy of the CAA to supersede the remedy of the Sherman Act, ${ }^{22}$ and thereby

\footnotetext{
17 Civil Aeronautics Act of 1938, $\$ 102,52$ Stat. 980 (now Federal Aviation Act of 1958, as amended, 72 Stat. 740, 49 U.S.C. $\$ 1302$ (1958)). This section prescribes the general duties and aims of the Aviation Act in accordance with the public interest. For a criticism of public interest standards see Miller, The Public Interest Undefined, 10 J. PUB. L. 184 (1961).

${ }_{18} 371$ U.S. at $308-09$.

10 Id. at 302-03, 310-11.

so Id. at $311-12$.

${ }^{21}$ Id. at 303, 312. The conclusion that the $\mathrm{CAB}$ had power to deal with pre-1938 transactions under $\$ \$ 11$ rejects the contrary position taken in Slick Airways v. American Airlines, lnc., 107 F. Supp. 199, 211 (D.N.J. 1951), petition denied, 204 F.2d 230 (3d Cir.), cert. denied, 346 U.S. 806 (1953).

${ }^{33} \mathrm{Id}$. at 313 n.19. The fact that the $\mathrm{CAB}$ had a power of divestment serves to answer the argument that the Board should not hear the case because it lacked power to grant the relief requested or needed. See Slick Airways v. American Airlines, Inc., note 21 supra, at 211; Schwartz, Primary Administrative Jurisdiction and the Exhaustion of Litigants, 41 GEO. L.J. 495 (1953). The power of divestment should
} 
solidified the Court's determination that the Board had primary and exclusive jurisdiction to deal with the antitrust issues of this and similar cases. ${ }^{23}$

The dissenters argued that such construction violates the rule against repeals by implication..$^{24}$ They contended that the Board not only lacked exclusive jurisdiction but was not even intended to have the authority to handle the antitrust problems presented. The dissenters noted that transactions approved by the Board under three sections of the CAA were given expresss statutory exemption from the antitrust laws ${ }^{25}$ but that no such exemption was accorded transactions approved under section 411. Also noting several lower court decisions that had rejected a supersession argument, ${ }^{26}$ the dissenters reasoned that section 411 was not repugnant to the antitrust laws and therefore there was no basis for a pro tanto repeal of those laws. ${ }^{27}$ The argument of the dissenters indicates that they place pri-

also prevent cases where the claimant effectively is left without a forum. See, e.g., Seatrain Lines v. Pennsylvania R.R., 207 F.2d 255 (3d Cir.), cert. denied, 345 U.S. 916 (1953). For a discussion of this judicial vacuum see Convisser, supra note 2, at 332.35.

${ }^{23}$ It seems implicit in the Court's decision that any transaction attacked under $\$ 411$ which the $C A B$ approves must be granted immunity from similar attack under the Sherman Act in the courts. See note 11 supra. Compare the Pan American case with United States v. Radio Corp. of America, 358 U.S. 334 (1959). In the latter case, an agency ruling that a certain transaction did not violate the antitrust laws was held not to immunize the parties from a similar antitrust attack in the courts. $A$ distin. guishing factor is that the FCC does not have the authority to determine antitrust issues as such. National Broadcasting Co. v. United States, 319 U.S. 190, 223 (1943).

${ }^{24} 371$ U.S. at 319-23. It is a general rule of construction that statutes are to be repealed by implication only in instances of clear repuguancy and only to the extent of the repuguancy. Sec, e.g., California v. FPC, 369 U.S. 482, 485 (1962); Georgia v. Pennsylvania R.R., 324 U.S. 439, 455-57 (1945); United States v. Borden Co., 308 U.S. $188,197-206$ (1939).

${ }^{26}$ Civil Aeronautics Act of 1938, $\$ 114,52$ Stat. 1004 (now Federal Aviation Act of 1958, as amended, 72 Stat. 770,49 U.S.C. $\$ 1384$ (1958)). See note 11 supra.

${ }^{26} 371$ U.S. at 323-24. For lower court cases construing $\$ 411$ sec, e.g., S.S.W., Inc. v. Air Trans. Ass'n, 191 F.2d 658 (D.C. Cir. 1951), cert. denied, 343 U.S. 955 (1952) (CAB had primary jurisdiction, but district court retained jurisdiction for injunctive relicf and damages); Apgar Travel Agency, Inc. v. International Air Trans. Ass'n, 107 F. Supp. 706 (S.D.N.Y. 1952) (same); Shick Airways v. American Airlines, Inc., 107 F. Supp. 199 (D.N.J. 1951), petition denied, 204 F.2d 230 (3d Cir.), cert. denied, 346 U.S. 806 (1953) (holding district court should hear entire case). In each of these cases the central problem dealt with was treble damages and in each the court held that the antitrust remedy had not been superseded by the CAA.

${ }^{27} 371$ U.S. at $319-24$. The dissenters further objected to the fact that the Board did not have juriscliction over Grace. Since Grace was a shipping line, they doubted that it fell within the classification of an "air carrier," necessary to come under $\$ 411$. Thus, the CAB could not adequately deal with the unhealthy situation at hand. Id. at 328-29. Although the Court did not rule that the $C A B$ had jurisdiction over Grace, the broad language of the opinion indicates that such jurisdiction was envisioned. Id. at 311-12.

It is possible that the Board could deal with Grace in a manner that was not 
mary importance on the principles of competition in the belief that the antitrust laws should be repealed only by express instruction of Congress. ${ }^{28}$ As a means of accommodation it was suggested that enforcement of the Sherman Act in the courts would settle the problems of Panagra's control and open the way for action by the $\mathrm{CAB}$ on service routes to Latin America. 29

Although the Court held that the remedy of the antitrust laws had been superseded by section 411 , it did not state the extent to which, if any, the substantive policy and rationale of the antitrust laws had been superseded. Such a question could arise only on judicial review of an agency ruling. ${ }^{30}$ Upon such review, a court will determine whether the agency has applied the correct statutory standards. In the past differences of opinion have arisen as to the role to be given to antitrust policies in giving content to the congressionally enunciated public interest standard..$^{31}$ Two possible approaches to this problem were illustrated in the case of McLean Trucking Co. $v$. United States. ${ }^{32}$ There the majority held that to

suggested. Grace would normally fall under $\$ 408,52$ Stat. 1001 (1938) (now Federal Aviation Act of 1958, as amended, 72 Stat. 767, 49 U.S.C. $\$ 1378$ (1958)), but the CAB has disclaimed jurisdiction under $\$ 408$ of pre-1938 formations. Railroad Control of Northeast Airlines, 4 C.A.B. 379, 386 (1943). Yet, the CAB has also stated that if the pre-1938 control position of a non-air carrier were substantially enhanced after 1938, the CAB could deal with the formation. See Pan American-Panagra Agreement, 8 C.A.B. 50, 56 (1947). Thus it would seem that if Pan American were divested of its holdings in Panagra by either the courts or the CAB, Grace's control position would be substantially enhanced and the Board could deal with Grace under $\$ 408$.

${ }^{28} 371$ U.S. at 322-24. See Schwartz, supra note 2, who supports a primacy of the antitrust laws position. See also Jaffe, supra note 2. It has also been argued that the courts can better envision the entire economy and are not limited to one industry as are the agencies. See Latta, supra note 2, at 294.

The dissenters also argued that a practical effect of the Court's decision is the probable extension of an already lengthy litigation. 371 U.S. at 327-28. See note 38 infra; see generally FuL.DA $\$$ 13.4-.6.

20371 U.S. at 330 . As an alternate means of decision the dissenters suggested that the doctrine of primary jurisdiction be invoked. Id. at 331-33. Since the dissenters contended that there was no basis for supersession, it seems apparent that they envisioned the Board as a mere fact-finding organ in this case. See FMB v. Isbrandtsen Co., 356 U.S. 481 (1958). As the dissent admitted, this means of accommodation would not achieve any practical results, for the Board's position is already known. 371 U.S. at 332.

${ }^{30}$ Federal Administrative Procedure Act $\$ 10,60$ Stat. 243 (1946), 5 U.S.C. $\S 1009$ (1958); see Latta, supra note 2, at 267.

${ }^{31}$ See McLean Trucking Co. v. United States, 321 U.S. 67 (1944); Furda § 1. See also Norfolk So. Bus Corp. v. United States, 96 F. Supp. 756, 761 (E.D. Va.), aff d per curiam, 340 U.S. 802 (1950) (commission to determine what practices within the public interest); compare ATT'Y GEN. NAT'L CoMM. ANTITRUST REP. 269-70 (1955) (antitrust should play a larger role).

${ }^{32} 321$ U.S. 67 (1944). The McLean case reviewed a consolidation of motor carriers approved by the ICC under $\$ 5$ of the Interstate Commerce Act, 63 Stat. 485 (1949), 
force the agency to give substantial application to antitrust policy under its public interest standard would render the exemption from the antitrust laws useless. ${ }^{33} \mathrm{Mr}$. Justice Douglas, the author of the present majority opinion, dissented on the ground that while the agency was not to be held to strict antitrust standards, a proper holding would give greater weight to the principles of competition and that only in cases of clear necessity should the substantive antitrust philosophy give way entirely. ${ }^{34}$ The Court in the Pan American case made several specific references to the use of the word "competition" in section 102 and also stated that the CAA was intended to enhance antitrust enforcement, not negate it..$^{35}$ Thus, it would seem that the Court intended for the $\mathrm{CAB}$ to consider substantive antitrust philosophy in its public interest standard in the manner urged by Justice Douglas in the McLean case when deciding cases that come within its primary and exclusive jurisdiction under section $411 .^{36}$

The Court's construction of section 411 (as giving the $\mathrm{CAB}$ primary and exclusive jurisdiction over the antitrust issues of the instant case) should produce several effects. The principal effect should be the achieving of uniformity of regulation by a supposedly expert Board. The Court asserted that such an effect was desirable because it would enable the GAB to handle issues that have "a particular relation" to the regulation of the aviation industry. ${ }^{37} \mathrm{An}$ -

49 U.S.C. $\$ 5$ (1958), which grants an exemption from the antitrust laws if the ICC approves. 49 U.S.C. $\S 5(11)(1958)$ (reasonable and consistent with the public interest). For a general discussion of the McLean case see FuLDA $\$ 5.24$.

s3 321 U.S. at $84-87$.

st Id. at $92,-94$.

35371 U.S. at 307 . It should be noted that the CAA is unique in that it places more emphasis on competition than the other federal transportation statutes. See FuLDA $\$ \S 2.6-.7,14.2$.

${ }^{30}$ See FMB v. Isbrandtsen Co., 356 U.S. 481 (1958), where the Court ruled that dual rate systems approved by the FMB under $\S 14$ of the Federal Maritime Act, 89 Stat. 733 (1916) (now 46 U.S.C. $\$ 812$ (1958)), were illegal per se, even though the Court had in Far East Conference v. United States, 342 U.S. 570 (1952); and United States v. Cunard S.S. Co., 284 U.S. 474 (1932), held that $\S 14$ of the FMA had superseded the antitrust laws. Thus, although the FMB had exclusive jurisdiction the Court retained the power to determine the applicability of the statute. For a discussion of the Isbrandtsen case see FuLDA $\$ 10.2$; see generally Comment, Primary Jurisdiction and the Applicability of Antitrust Remedies in the Shipping Industry, $20 \mathrm{U}$. CrI. I. REv. 598 (1959).

The Pan American case presents an even stronger case for retention of judicial powers because $\S 14$ of the FMA had an express provision giving approved transactiong immunity from the antitrust laws and no such provision can be found for $\$ 411$.

${ }^{37} 371$ U.S. at 311 . For a criticism of regulatory agencies, particularly the CAB, see Hector, Problems of the CAB and the Independent Rcgulatory Commissions, 69 YALE L.J. 931 (1960); see also, Schwartz, supra note 2, at 436-38, 471-75. 
other apparent effect of the decision should be that the CAB will be required to take cognizance of antitrust policy when deciding cases under section 411. Moreover, a practical effect of the Court's interpretation could be the prevention of divestments that would prove costly to the airline involved, since the $\mathrm{CAB}$ can approve transactions as being in the public interest even though they are technical violations of the Sherman Act.

Although the doctrine of primary jurisdiction has generally been accepted as necessary for accommodating the regulatory statutes and the antitrust laws, its application by the courts has been criticized as time consuming, ${ }^{38}$ as being mechanically applied,,${ }^{39}$ and as an abdication of judicial responsibility. ${ }^{40}$ Even though the decision in the Pan American case can be so criticized, the Court is not likely to change its position and the Congress has shown little willingness to react to such decisions. ${ }^{41}$ Moreover, while this decision ostensibly points toward greater power for administrative agencies, it should not be assumed that the Court ignored past criticism. Both the majority and the dissent properly characterized the problem as one of statu-

${ }^{38}$ The time consumed by agency-court-agency and court-agency-court cases has bothered the commentators. They are particularly critical of the Cunard, Far East, Isbrandtsen series of cases which took twenty-five years to decide a point that could have been settled when the Cunard case was first heard, i.e., that dual rate systems are per se illegal under the Federal Maritime Act. See note 36 supra. See generally FuLDA $\$$ 13.4-.6, and Latta, supra note 2, at 295.

${ }^{30}$ Jaffe, supra note 2, at 589-91.

10 See Schwartz, Legal Restriction of Competition in the Regulated Industries: An Abdication of Judicial Responsibility, 67 HARv. L. REv. 436 (1954). Professor Davis has argued that Professor Schwartz's attack is misdirected because primary jurisdiction merely helps courts to determine if they should act with or without the benefit of the agency; rather, Davis argues that the difficulty lies with the possible lack of judicial review. 3 DAvis $\$ 19.05$. Another commentator has pointed out that while much of Schwartz's criticism may be vahd, Congress has seemingly acquiesced by its prolonged silence. Latta, supra note 2 , at 287 .

For general criticisms of the administrative process see Staff of Senate Comm. on THE Judiciary, 86TH CoNG., 2D. Sess., Rep. ON THE Regulatory Agencies to the PresiDENT-Elect (Comm. Print 1960); Hanslowe, The Malaise of the Administrative Process, 1962 Duke L.J. 477; Hector, supra note 37.

${ }^{11}$ After Georgia v. Pennsylvania R.R., 324 U.S. 439 (1945), in which it was held that the Interstate Commerce Act was no bar to enjoining a carrier for antitrust violations, Congress passed the Reid-Bulwinkle Act, 62 Stat. 472 (1948), 49 U.S.C. $\$ 5$ (b) (1958), which gave immunity from antitrust attack to similar practices if approved by the ICC. After FMB v. Isbrandtsen Co., 356 U.S. 481 (1958), in which the Supreme Court declared a dual rate system per se illegal under the Shipping Act, Congress amended the Shipping Act to give the FMB power to approve dual rate systems. 72 Stat. 574, 46 U.S.C. $\$ 812$ (1958); see FuLDA $\$ \$ 10.3-.4$.

Congressman Celler introduced a bill three times, yet to be enacted, which provides that unless the statute expressly provides otherwise, antitrust suits will not be barred or stayed for any reason. See FuLDA $\$ 13.4$. 
tory construction. ${ }^{42}$ This approach is sounder than mere deference to expertise and uniformity ${ }^{43}$ and if followed, should lead to more satisfactory accommodation of the two regimes and better application of the congressional purpose. ${ }^{44}$ Furthermore, if the courts will require the $\mathrm{CAB}$ to display sufficient cognizance of substantive antitrust policy when applying its standards, as the Court indicated it would, then the traditional principles of competition will play an important role in the regulation of the aviation industry.*

12 See California v. FPC, 369 U.S. 482 (1962), where the Court held that the Federal Power Commission could not proceed on a merger application until an antitrust suit concerning the same merger had been handled in the courts. Although this decision appears to conflict with the Pan American case, it was in fact an attempt to handle accommodation of the two regimes by proper statutory construction. See, BNA, ANTITRUST \& TRADE Regulation Report No. 87, p. B1-B4 (March 12, 1963) (discussing both cases). For a recent decision involving an agency in which considerable statutory construction was indulged in see Arrow Transp. Co. v. Southern Ry., 372 U.S. 658 (1963).

${ }^{3}$ Commentators have asserted that the courts have too often paid homage to the agencies for no apparent reason other than deference to uniformity and alleged expertise. They argue that in reality these bases for invoking primary jurisdiction have been overvalued. The supposedly expert members of agencies are sometimes political appointees, often industry oriented, and always overburdened. Also, uniformity is a desirable effect, but it should not be an end in itself. The proper goal is the achievement of the congressional purpose. Sce generally Convisser, supra note 2, at 328-30, 336-37; Hector, supra note 37; Jaffe, supra note 2, at 577-81, 603.04; Schwartz, supra note 2, at 271-75.

st The proper goal would appear to be the fulfillment of the congressional purpose with an eye toward speedy solution of antitrust cases. This, of course, will call for a careful delinention of the purposes and the functions of the courts and the agencics. "[W] hat is required is not an indiscriminate but a selective application of the rule [of primary jurisdiction], attainable only by the test of legislative intent." Convisser, supra note 2, at 337. (Emphasis added.) Sce generally FuLdA $\$ \$ 13.5-.6$, and Latta, supra note 2, at 294-95 (both argue for a splitting of the causes where possible and necessary). But see Hale \& Hale, Competition or Control IV: Air Carriers, 109 U. PA. L. REv. 311 (1961) (antitrust laws hinder the regulation of aviation industry by the $\mathrm{CAB}$ ).

* After this note had gone to press, the CAB issued a statement which reveals the CAB's interpretation of the Pan American decision and indicates how the CAB intends to utilize its newly discovered powers. On or about July 15,1963 , the CAB announced that a proceeding would be held to hear a proposal by Pan American that it be allowed to purchase Grace's interest in Panagra. The same announcement noted the Board's tentative rejection of the Pan American proposal and stated that it would be in the public interest for Pan American and Grace to sell their interests in Panagra to Braniff Airlines, which competes with Panagra in South America. Sec N. Y. Times, July 18, 1963, p. 42, col. 4; 371 U.S. at 314-19. The CAB asserted that such a voluntary sale would "avoid the expensive litigation which will otherwise be necessary to complete the investigation." N. Y. Times, July 19, 1963, p. 32, col. 4. Pan American, of course, rejected the GAB's suggestion. Ibid. Although the premature "shotgun mar. riage" declaration of the Board is disturbing, for the purposes of this note attention can more profitably be focused on the form and scope of the investigation the CAB intends to make.

The CAB stated that on authority of the Pan American case it would investigate whether Pan American or Grace (or both) had violated the Federal Aviation Act 
either through the original agreements or in the management of Panagra. See N. Y. Times, July 18,1963 , p. 42 , col. 4. Thus, the CAB obviously reasons that the Pan American decision has endowed it with jurisdiction over Grace. See note 27 supra. Also, by investigating the original agreements, the $C A B$ will be scrutinizing pre-1938 activities and transactions. See notes 19 \& 21 supra and accompanying text. The Board further stated that it would consider whether Pan American or Grace ( or both) should be required to divest their holding in Panagra if either (or both) had engaged in unfair competitive practices. See notes $20,22 \& 23$ supra and accompanying text.

Although the $\mathrm{CAB}$ has not in fact rendered a decision, the statement discussed above leaves little doubt as to the outcome of the proceeding. By forcing Pan American and Grace to sell Panagra to Braniff, the Board will to a large degree effectuate the type of monopoly it was supposedly trying to prevent when it urged the Justice Department to bring suit in the Pan American case. See note 13 supra. While the $\mathrm{CAB}$ has correctly estimated its powers under the Pan American case (jurisdiction over Grace, jurisdiction over pre-1938 transactions, and power of divestiture), it has apparently neglected to take cognizance of the underlying holding of the opinion: the principles of competition are to play an important role in regulating the aviation industry in accordance with the articulated congressional policy. 